\title{
The Metallurgical and Materials Professional Engineering Examination: October 2015 and Beyond
}

Henry J. White, Michael Burns, and Deborah Fourney

\section{Introduction}

Professional Engineering (PE) licensure indicates to employers, clients, and colleagues that an engineer has attained the highest standard of skill, knowledge, and professionalism. Although a great honor to achieve, PE licensure is also becoming a necessary credential for engineers who offer their services to the public. As stated by the National Council of Examiners for Engineering and Surveying (NCEES), the governing body for professional licensure in the United States, "The goal of licensing is to determine whether an individual is minimally competent to practice engineering." The NCEES further notes that "these individuals must demonstrate that they have the basic knowledge required to practice without endangering the health, safety, and welfare of the public."

PE licensure, by nature of its rigor, does not occur overnight and requires the following steps:

- Earn a four-year degree from an accredited engineering program.

- Pass the Fundamentals of Engineering (FE) examination. This covers basic math, science, and engineering principles and is often taken during or shortly after the senior year of college.

- Complete four years of progressive engineering experience under a PE's supervision.

- Pass the Principles and Practice of Engineering (PE) exam in a specific engineering discipline.

The metallurgical and materials version of the PE examination has undergone changes to examination specification and other administrative elements that will be implemented in October 2015. The most significant changes to the metallurgical and materials PE examination specification are:

- Removal of foundation topics because these questions are more suitable for the Fundamentals of Engineering examination.

- Addition of questions incorporating engineering standards and specifications because these are more suitable for PE candidates with three to five years of experience who are seeking licensure.

The PE exam is administered by state licensure boards, which are provided the test instrument by the NCEES. The NCEES scores the examinations. The metallurgical and materials examination is developed by volunteer members of the TMS Professional Registration Committee. The committee's responsibilities include serving as a liaison with the NCEES and preparing, writing, and reviewing items for the examination. TMS is the only materials professional society to have formal responsibility for providing leadership in the establishment and fulfillment of professional registration standards for the metallurgical and materials communities.

\section{Re-certification of the Metallurgical and Materials PE Examination Specification}

Every six to eight years, the TMS Professional Registration Committee undertakes a rigorous Professional Activity and Knowledge Study (PAKS). The PAKS includes a survey of licensed engineers in the field of metallurgy and materials on what knowledge a PE candidate with four years of experience should have to protect public health, safety, and welfare. The results of the survey are tabulated and reviewed by a panel from the TMS Professional Registration Committee. The panel then advises the NCEES on the topics to be tested and the proportion of questions from each topic area. A comparison between the previous (2009) and the new (2015) metallurgical and materials PE examination specification is presented in Tables Ia and $\mathrm{Ib}$ on the following two pages.

Table Ia displays the main differences between the current and the new examination specifications. The topics in red type will be eliminated in 2015. Although Table Ia shows that solidification and chemical resistance have been omitted as topics, these types of questions will probably be maintained in areas such as welding and corrosion, respectively.

Table Ib displays the areas that were added to the examination specification in red type. There will be a major emphasis on engineering standards and specifications as well as an emphasis on failure, fatigue, fitness for service, and life-extension-type analyses. Table $1 \mathrm{~b}$ also provides a detailed description of the new metallurgical and materials PE examination specification. These changes go into effect with the October 2015 examination and may be maintained for the next six to eight years. These most recent changes in the examination specification will also necessitate changes to the suggested reference list and exam study guide. Those planning to take the October 2015 examination should check the TMS 
website (www.tms.org/Education/PE/PE.aspx) for new test preparation material.

\section{Computer-Based Testing: A Future Change in the PE Examination Format}

Another expected change that will occur sometime in the near future is a change in examination format from pencil and paper to computer-based testing (CBT). The Fundamentals of Engineering examination went CBT in early 2014 and the NCEES has approved converting PE examinations to CBT format as early as 2015 . However, the October 2015 metallurgical and materials PE examination will not be CBT. The TMS Professional Registration Committee is working closely with the NCEES on a CBT format for the metallurgical and materials community and will provide sufficient warning as to when this change will occur.

\section{NCEES and ABET Synergies}

The first step toward PE licensure is earning a bachelor's degree from an educational institution with an ABET Engineering Accreditation Commission (ABET/EAC) engineering program. (Table II lists the 62 U.S. educational institutions that currently have metallurgical and materialsrelated ABET/EAC accredited programs.) Such a degree program provides state licensure boards with the guarantee that the candidate has the necessary education to qualify for engineering licensure. ABET, the governing body for engineering education in the United States, maintains criteria that educational institutions must satisfy to achieve

\begin{tabular}{|c|c|}
\hline & Table la. 2009-2014 E \\
\hline $\begin{array}{l}\text { I. Fundamental Topics } \\
\text { (33\%/ 26-27 questions) }\end{array}$ & $\begin{array}{l}\text { II. Structure and Properties } \\
\text { (30\%/ } 24 \text { questions) }\end{array}$ \\
\hline $\begin{array}{l}\text { A. Statistics } \\
\text { (5\%/ } 4 \text { questions) } \\
\text { 1. Confidence Intervals } \\
\text { 2. Data Analysis } \\
\text { 3. Application to Quality Control } \\
\text { 4. Process Quality Control }\end{array}$ & $\begin{array}{l}\text { A. Structure/ Phase/Transformations } \\
\text { (10\%/ } 8 \text { questions) } \\
\text { 1. Crystal Structure } \\
\text { 2. Phase Diagrams } \\
\text { 3. Solidification } \\
\text { 4. Phase Transformations } \\
\text { 5. Diffusion } \\
\text { 6. Chemistry }\end{array}$ \\
\hline
\end{tabular}

\section{B. Physical/Engineering Sciences \\ (11\%/ 8-9 questions) \\ 1. Physical Chemistry \\ 2. Phase Equilibria \\ 3. Thermodynamics \\ 4. Heat Transfer \\ 5. Reaction Kinetics}

\section{Mechanics of Materials (5\%/ 4 questions) \\ 1. Statics \\ 2. Dynamics}

\section{B. Mechanical Properties of Metals and Materials (10\%/ 8 questions) 1. States of Stress \\ 2. Strengthening Mechanisms \\ 3. Cold Work and Annealing \\ B. Surface Modification (5\%/ 4 questions) 1. Diffusion Treatment 2. Coatings \\ 3. Thermal Treatments}

4. Elastic/Plastic Deformation

5. Fracture Mechanics

6. Fatigue Analysis and Life Prediction

7. High Temperature Behavior

8. Mechanical Behavior of Composites

C. Application and Specifications of
Metals and Materials Selection
( $10 \% / 8$ questions)
1. Mechanical Performance
2. Chemical Resistance
3. Thermal Stability
4. Corrosion/Environmental Compatability
5. Temperature/Radiation or Other
Environmental Compatabilities

A. Heat Treatment
(7\%/5-6 questions)
1. Ferrous Alloys
2. Nonferrous Alloys
3. Polymers, Ceramics and Glasses

\section{Forming and Fabrication (9\%/ 7-8 questions)}

1. Joining

2. Casting

3. Bulk Forming

4. Powder Processing

5. Material Removal Processes
IV. Performance

(16\%/ 12-13 questions)

\section{A. Material Testing \\ (8\%/6-7 questions) \\ 1. Mechanical Testing \\ 2. Nondestructive Testing \\ 3. Chemical Analysis Techniques \\ 4. Metallography \\ 5. Electron Microscopy \\ 6. X-ray Diffraction Application/ Analysis \\ 7. Environmental Test Methods}

\section{B. Material Degradation (7\%/5-6 questions) 1. Corrosion and Wear Mechanisms 2. High Temperature Oxidation 3. Embrittlement}

\section{Process Fundamentals (12\%/ 9 -10 questions) \\ 1. Mass Balance \\ 2. Heat Balances \\ 3. Thermodynamics \\ 4. Kinetics \\ 5. Heat Transfer \\ 6. Electrochemistry}

Areas in red type are not included on the 2015 examination specification. 


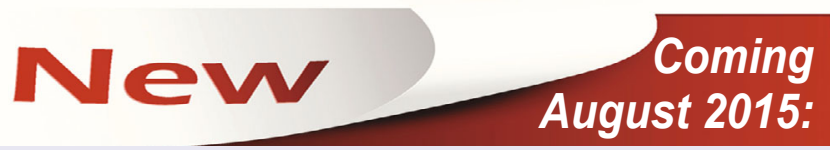

TMS Offers PE Exam Preparation Course

Strengthen your confidence and preparation for the October 2015 Professional Engineering (PE) licensing examination. Plan now to enroll in the PE Examination Preparation Course offered by TMS-the first of its kind developed specifically for the metallurgical and materials version of the PE examination. Taught by instructors from both academia and industry, the course will take place in August 2015 at TMS headquarters in Warrendale, Pennsylvania.

The TMS PE Examination Preparation Course will address a variety of approaches and methodologies, including design, analysis, application, and operations. It will also include "refresher training" on ferrous materials, light and nonferrous materials, ceramics, polymers, composites, and electronic materials. The specific knowledge areas covered in the course will reflect the October 2015 examination specifications.

Updates and additional information on the course will be posted on the TMS website and published in future issues of JOM, as well as other TMS communications.

Please note that because of its role in the development of the PE examination, the TMS Professional Registration Committee has no involvement with the development of this course. accreditation. Accredited institutions are then re-evaluated every six years to make sure that their programs continue to satisfy these criteria. Within these criteria, there are a number of aspects related to licensure, including:

- An accredited engineering program has developed educational objectives or statements that describe what a student should be able to accomplish three to five years after graduation. These generally relate to what needs to be accomplished to become a licensed professional engineer.

- An accredited engineering program has also formulated student outcomes or statements that describe what a student should know at or around the time of graduation. These generally relate to the skills and knowledge needed to pass the Fundamentals of Engineering examination. Several ABET/EAC accredited engineering programs use FE examination results to evaluate the extent to which their students have attained their student outcomes.

- Engineering programs must demonstrate continuous improvement as an ABET/EAC criterion for accreditation. Most state boards likewise require

Table lb. Examination Specification Effective 2015



New areas in red type.

Note the addition of standards and specifications in all specification areas 


\section{Table II. Universities/Institutions That Have ABET/EAC Metallurgical and Materials Related Accredited Programs}

\begin{tabular}{|c|c|c|}
\hline School Name & Accreditation Dates & Date of Next Review \\
\hline$\overline{\text { Alfred University }}$ & 1976-Present & $2017-2018$ \\
\hline Arizona State University & 1996-Present & $2015-2016$ \\
\hline Auburn University & 1975-Present & $2016-2017$ \\
\hline Boise State University & 2005-Present & 2016-2017 \\
\hline Brown University & 1967-Present & $2014-2015$ \\
\hline California Polytechnic State University, San Luis Obispo & 1971-Present & $2014-2015$ \\
\hline Carnegie Mellon University & 1936-Present & $2018-2019$ \\
\hline Case Western Reserve University & 1936-Present & 2018-2019 \\
\hline Colorado School of Mines & 1936-Present & $2018-2019$ \\
\hline Cornell University & 1951-Present & $2016-2017$ \\
\hline Drexel University & 1953-Present & 2013-2014 \\
\hline Georgia Institute of Technology & 1942-Present & $2014-2015$ \\
\hline Illinois Institute of Technology & 1949-Present & 2014-2015 \\
\hline lowa State University & 1999-Present & 2018-2019 \\
\hline Lehigh University & 1936-Present & $2013-2014$ \\
\hline Massachusetts Institute of Technology & 1936-Present & 2013-2014 \\
\hline Michigan State University & 1985-Present & $2016-2017$ \\
\hline Michigan Technological University & 1965-Present & $2017-2018$ \\
\hline Missouri University of Science and Technology & 1936-Present & $2014-2015$ \\
\hline Montana Tech of the University of Montana & 1937-Present & 2016-2017 \\
\hline New Mexico Institute of Mining and Technology & 1991-Present & $2016-2017$ \\
\hline North Carolina State University at Raleigh & 1969-Present & $2016-2017$ \\
\hline Northwestern University & 1976-Present & $2017-2018$ \\
\hline Pennsylvania State University & 1938-Present & 2014-2015 \\
\hline Purdue University at West Lafayette & 1941-Present & 2013-2014 \\
\hline Rensselaer Polytechnic Institute & 1938-Present & $2013-2014$ \\
\hline Rutgers, The State University of New Jersey & 1949-Present & $2018-2019$ \\
\hline San Jose State University & 1962-Present & $2017-2018$ \\
\hline South Dakota School of Mines and Technology & 1936-Present & $2016-2017$ \\
\hline The Johns Hopkins University & 1982-Present & $2017-2018$ \\
\hline The Ohio State University & 1992-Present & $2017-2018$ \\
\hline The University of Akron & 2000-Present & $2013-2014$ \\
\hline The University of Alabama & 1949-Present & 2013-2014 \\
\hline University of Alabama at Birmingham & 1983-Present & 2018-2019 \\
\hline University of Arizona & 1950-Present & $2016-2017$ \\
\hline University of California, Berkeley & 2005-Present & 2018-2019 \\
\hline University of California, Davis & 1990-Present & 2018-2019 \\
\hline University of California, Irvine & 2003-Present & 2013-2014 \\
\hline University of California, Los Angeles & 1985-Present & $2018-2019$ \\
\hline University of California, Riverside & 2011-Present & 2018-2019 \\
\hline University of Cincinnati & 1948-Present & $2017-2018$ \\
\hline University of Connecticut & 2005-Present & 2013-2014 \\
\hline University of Florida & 1971-Present & $2018-2019$ \\
\hline University of Idaho & 2006-Present & $2013-2014$ \\
\hline University of Illinois at Urbana - Champaign & 1994-Present & $2013-2014$ \\
\hline University of Kentucky & 1936-Present & $2016-2017$ \\
\hline University of Maryland College Park & 1998-Present & $2017-2018$ \\
\hline University of Michigan & 1936-Present & $2017-2018$ \\
\hline University of Minnesota - Twin Cities & 1984-Present & $2013-2014$ \\
\hline University of Nevada, Reno & 1955-Present & $2017-2018$ \\
\hline University of Pennsylvania & 1949-Present & $2017-2018$ \\
\hline University of Pittsburgh & 1988-Present & $2017-2018$ \\
\hline University of Tennessee at Knoxville & 1964-Present & $2017-2018$ \\
\hline University of Texas at El Paso & 1947-Present & 2013-2014 \\
\hline University of Utah & 1936-Present & $2015-2016$ \\
\hline University of Washington & 1936-Present & 2013-2014 \\
\hline University of Wisconsin - Madison & 1993-Present & 2018-2019 \\
\hline University of Wisconsin - Milwaukee & 1969-Present & $2014-2015$ \\
\hline Virginia Polytechnic Institute and State University & 1948-Present & $2013-2014$ \\
\hline Washington State University & 1936-Present & 2013-2014 \\
\hline Winona State University & 1992-Present & $2017-2018$ \\
\hline Wright State University & 1979-Present & $2017-2018$ \\
\hline
\end{tabular}

active licensed PEs to demonstrate continuous self-improvement and education.

- The cornerstone of any ABET/EAC accredited engineering program is a high-quality faculty. ABET does list Professional Engineering licensure as one of the methods for determining faculty competency.

- One ABET/EAC curriculum criterion requires that students are prepared through a major design experience "incorporating appropriate engineering standards." Candidates for licensure need to be well acquainted with engineering standards as preparation for the October 2015 PE examination.

- Specifically for metallurgical and materials engineering programs, $\mathrm{ABET} / \mathrm{EAC}$ requires coverage of the structure, properties, processing, and performance of materials. The October 2015 metallurgical and materials PE examination is organized according to these four elements.

Earning a degree from an ABET/

EAC accredited engineering program assures a strong start toward becoming a Professional Engineer. A degree from an educational institution with an unaccredited engineering program may cost the aspiring candidate hundreds of dollars in additional education justification fees and two or more years delay along the pathway to professional engineering licensure.

\section{Acknowledgements}

The authors would like to thank: Tim Miller, NCEES Director of Exam Service; Jason Gamble, NCEES Exam Development Engineer; and TMS Professional Registration Committee colleagues who took the time to review this article. Please direct any questions related to the content of this article to TMSCommitteeChair pe@tms.org.

\footnotetext{
Henry J. White, CB\&I, is the Past Chair, TMS Professional Registration Committee, and Michael Burns, Stress Engineering Services, is the current Professional Registration Committee Chair. Deborah Fourney, Metallurgical Technologies Inc., is Professional Registration Committee Vice Chair.
} 